VNU Journal of Science: Legal Studies Journal homepage: https://js.vnu.edu.vn/LS

Review Article

\title{
Product Liability Law: From Theory to Prative in Vietnam
}

\author{
Nguyen Thi Que Anh*, Nguyen Bich Thao \\ VNU School of Law, 144 Xuan Thuy, Cau Giay, Hanoi, Vietnam
}

Received 13 July 2020

Revised 14 August 2020; Accepted 28 September 2020

\begin{abstract}
Product liability law plays an important role in protecting consumers in the modern society. This article analyzes the development of product liability law in the world, presents the concept and characteristics of product liability, examines product liability law in the United States and European Union, and compares with Vietnamese law on protection of consumer rights. The article also surveys some cases decided by Vietnamese courts in which consumers claimed damages for companies' infringement on their rights, and points out the loopholes and shortcomings of the law and of the courts' application of law. The authors then argue that these shortcomings result from the lack of an independent body of product liability law which is based on sound theoretical foundation, and proposes directions to address this problem.
\end{abstract}

Keywords: Product liability, compensation for damage, protection of consumer rights.

\footnotetext{
${ }^{*}$ Corresponding author.

E-mail address: queanhthu@yahoo.com

https://doi.org/10.25073/2588-1167/vnuls.4310
} 


\title{
Pháp luật về trách nhiệm sản phẩm: Từ lí thuyết đến thực tiễn ở Việt Nam
}

\author{
Nguyễn Thị Quế Anh*, Nguyễn Bích Thảo \\ Khoa Luật, Đại học Quốc gia Hà Nội, 144 Xuân Thủy, Cầu Giấy, Hà Nội, Việt Nam \\ Nhận ngày 01 tháng 4 năm 2020 \\ Chỉnh sửa ngày 08 tháng 9 năm 2020; Chấp nhận đăng ngày 10 tháng 9 năm 2020
}

\begin{abstract}
Tóm tắt: Pháp luật về trách nhiệm sản phẩm có vai trò quan trọng trong việc bảo vệ người tiêu dùng trong xã hội hiện đại Bài viết khái quát sự phát triển của pháp luật về trách nhiệm sản phẩm trên thế giới, khái niệm và các đặc điểm của trách nhiệm sản phẩm, khảo sát pháp luật trách nhiệm sản phẩm của Hoa Kỳ và Liên minh châu Âu, từ đó so sánh với các quy định pháp luật Việt Nam về bảo vệ quyền lợi người tiêu dùng. Bài viết cũng phân tích thực tiễn xét xử một số vụ án về bồi thường thiệt hại do vi phạm quyền lợi người tiêu dùng ở Việt Nam trong những năm gần đây để thấy được những hạn chế trong quy định của pháp luật và trong thực tiễn áp dụng pháp luật của tòa án. Các tác giả lập luận rằng những bất cập đó xuất phát từ sự thiếu vắng một chế định độc lập về trách nhiệm sản phẩm dựa trên nền tảng lý luận vững chắc, và đưa ra định hướng hoàn thiện pháp luật Việt Nam về lĩnh vực này.
\end{abstract}

Tư khóa: Trách nhiệm sản phẩm, bồi thường thiệt hại, bảo vệ quyền lợi người tiêu dùng.

\section{Khái quát sự phát triển của pháp luật về trách nhiệm sản phẩm trên thế giới}

Trong mối tương quan giữa các nhà sản xuất, cung ứng hàng hóa, dịch vụ và người tiêu dùng thì người tiêu dùng luôn luôn ở vị thế yếu hơn. Nhà sản xuất, cung ứng sản phẩm là các thương nhân có kinh nghiệm và luôn nắm giữ thông tin đầy đủ hơn về sản phẩm so với người tiêu dùng. Trong khi đó, người tiêu dùng là chủ thể trực tiếp sử dụng hàng hóa phải hàng ngày, hàng giờ đối mặt với nguy cơ mất an toàn và bị thiệt hại do hàng hóa kém chất lượng hoặc có khuyết tật gây ra. Xã hội càng phát triển, nhu

\footnotetext{
"Tác giả liên hệ.

Địa chỉ email: queanhthu@yahoo.com

https://doi.org/10.25073/2588-1167/vnuls.4310
}

cầu bảo vệ người tiêu dùng - bên yếu thế càng được đặt ra cấp thiết. Pháp luật bảo vệ người tiêu dùng là công cụ pháp lý quan trọng đáp ứng đòi hỏi này. Trong quá trình hoàn thiện lĩnh vực pháp luật này, các quy định pháp luật về trách nhiệm sản phẩm đã ra đời nhằm đáp ứng yêu cầu bảo vệ người tiêu dùng một cách đầy đủ và hữu hiệu hơn trong xã hội hiện đại. Luật trách nhiệm sản phẩm (product liability) xuất hiện đầu tiên ở Hoa Kỳ khoảng giữa thế kỷ $\mathrm{XX}$, sau đó được tiếp nhận bởi các quốc gia ở Liên minh Châu Âu, ở Châu Á (như Nhật Bản, Hàn Quốc, Trung Quốc, các quốc gia Đông Nam Á).

Sự phát triển của pháp luật về trách nhiệm sản phầm đã trải qua nhiều giai đoạn với xu hướng ngày càng mở rộng phạm vi trách nhiệm của các nhà sản xuất. Trong thời kỳ đầu của 
cuộc cách mạng công nghiệp lần thứ nhất, khi sản xuất công nghiệp còn thô sơ, bên mua và bên bán thường ở cùng một khu vực, nhiều khi là quen biết nhau. Bên bán thường đồng thời là thợ thủ công trực tiếp làm ra sản phẩm. Việc mua bán diễn ra dưới hình thức hai bên trực tiếp gặp gỡ, thương lượng với vị thế tương đối bình đẳng. Các sản phẩm được mua bán, trao đổi thời kỳ đó cũng tương đối đơn giản và người mua có thể dễ dàng kiểm tra, đánh giá chất lượng $[1 ; 17]$. Do đó, nhu cầu bảo vệ người mua - người tiêu dùng chưa đặt ra cấp thiết. Hơn nữa, với chính sách thúc đẩy nền kinh tế tự do cạnh tranh, thúc đẩy thương mại phát triển, hạn chế sự can thiệp của nhà nước, pháp luật các nước tư bản chủ nghĩa thời kỳ đầu có xu hướng nghiêng về bảo vệ các doanh nghiệp, trách nhiệm sản phẩm chỉ đặt ra đối với trường hợp giữa người sản xuất và người mua có quan hệ hợp đồng trực tiếp với nhau, tức là nhà sản xuất đồng thời là nhà phân phối, nhà bán lẻ $[1$; 19]. Trong trường hợp nhà sản xuất ở cách xa so với người tiêu dùng trong chuỗi sản xuất, cung ứng sản phẩm (tức là sản phẩm đến tay người tiêu dùng thông qua một số khâu trung gian tiêu thụ), nhà sản xuất không phải chịu trách nhiệm trực tiếp đối với người tiêu dùng do chủ thể này được "che chắn" bởi học thuyết về trách nhiệm dựa trên mối liên hệ hợp đồng (privity of contract) [2]. Tình trạng này được duy trì cho đến đầu thế kỷ XX. Trong nhiều vụ kiện về vi phạm hợp đồng liên quan đến hàng hóa có khuyết tật, tòa án thường tuyên bên bán hàng không phải chịu trách nhiệm nếu trong hợp đồng bên bán không đưa ra cam kết rõ ràng về chất lượng đối với bên mua. Thậm chí, một số tòa án còn yêu cầu trong hợp đồng phải có cụm từ "bảo đảm" (warrant, guarantee) kèm theo cam kết về chất lượng thì bên bán mới phải chịu trách nhiệm về sản phẩm. Có nhiều lập luận để lý giải cho sự hạn chế của pháp luật trách nhiệm sản phẩm thời kỳ này. Thứ nhất, với sự thống trị của học thuyết tự do ý chí trong thời kỳ đầu của nền kinh tế tư bản chủ nghĩa, quan niệm truyền thống cho rằng người bán và nhà sản xuất sẽ chỉ phải chịu trách nhiệm đối với khuyết tật của hàng hóa do họ cung cấp nếu họ đã chủ động, tự nguyện gánh chịu trách nhiệm đó bằng một cam kết, thỏa thuận rõ ràng trong hợp đồng với bên mà họ trực tiếp giao dịch. Thứ hai, thời kỳ này, nhà nước muốn thúc đẩy quá trình công nghiệp hóa thông qua việc hạn chế các vụ kiện về trách nhiệm sản phẩm mà có thể dẫn đến những khoản bồi thường thiệt hại khổng lồ, có khả năng làm sụp đổ các doanh nghiệp mới trong các ngành công nghiệp non trẻ. Thứ ba, sự hạn chế trách nhiệm sản phẩm thời kỳ này cũng không ảnh hưởng bất lợi quá nhiều đến người tiêu dùng, vì như đã nói ở trên, người bán cũng đồng thời là người sản xuất và có quan hệ hợp đồng trực tiếp với người mua [2].

Tuy nhiên, cuối thế kỷ XIX, đầu thế kỷ XX, khi nền sản xuất công nghiệp ngày càng tăng trưởng mạnh mẽ, khoảng cách giữa người sản xuất, người bán và người mua ngày càng xa dần. Các sản phẩm công nghiệp ra đời ngày càng phong phú, đa dạng, phức tạp, tinh vi, được sản xuất bởi các dây chuyền lớn ở những nơi rất xa so với địa bàn mà sản phẩm được tiêu thụ. Người sản xuất không còn trực tiếp bán hàng đển tận tay người tiêu dùng nữa mà thông qua một hệ thống phân phối (các nhà bán buôn) rồi đến các nhà bán lẻ. Việc xác lập quan hệ hợp đồng trực tiếp giữa nhà sản xuất và người tiêu dùng không còn khả thi; do đó, các quy định pháp luật truyền thống không thể buộc nhà sản xuất chịu trách nhiệm đối với khuyết tật của sản phẩm bởi giữa họ và người tiêu dùng không có quan hệ hợp đồng. Điều này rõ ràng là bất công bởi lẽ các nhà sản xuất ngày càng phát triển, trở thành các doanh nghiệp lớn, trong đó có nhiều công ty đa quốc gia có tiềm lực tài chính và vị thế đàm phán rất mạnh so với người tiêu dùng là các cá nhân bình thường, nhỏ bé; trong khi đó, sản phẩm do các doanh nghiệp này sản xuất ra ngày càng chứa đựng nhiều mối nguy hiểm hơn đối với đời sống con người, chẳng hạn như xe máy, ô tô, máy bay, các thiết bị gia dụng,... Tính chất phức tạp và mức độ nguy hiểm gia tăng của hàng hóa khiến người mua không thể tự mình kiểm tra sản phẩm như thời kỳ trước đây. Về mặt chính sách, các ngành công nghiệp ở giai đoạn này đã phát triển và có chỗ đứng vững chắc trong nền kinh tế, do đó, pháp luật trách nhiệm sản phẩm cũng không 
cần thiết bảo vệ các nhà sản xuất một cách quá mức trước các vụ kiện đòi bồi thường do khuyết tật của hàng hóa [2].

Sự biến đổi của xã hội hiện đại đặt ra nhu cầu cấp thiết phải cải cách pháp luật về trách nhiệm sản phẩm, đưa ra các học thuyết mới để buộc nhà sản xuất - chủ thể ở cách xa so với người tiêu dùng - phải chịu trách nhiệm bồi thường đối với khuyết tật do sản phẩm gây ra. Nguyên tắc áp dụng trách nhiệm sản phẩm chỉ dựa trên mối liên hệ hợp đồng giữa các bên dần dần được nới lỏng với một số ngoại lệ, chẳng hạn nếu bên bán hoặc nhà sản xuất có hành vi bất cẩn (negligence) dẫn đến khuyết tật của hàng hóa và gây thiệt hại cho người tiêu dùng thì phải chịu trách nhiệm. Như vậy, từng bước, pháp luật về bồi thường thiệt hại ngoài hợp đồng do hành vi bất cẩn đã phát triển trong lĩnh vực trách nhiệm sản phẩm để phá vỡ lá chắn về "mối liên hệ hợp đồng", buộc nhà sản xuất ở cách xa trong chuỗi sản xuất, cung ứng cũng phải bồi thường, nếu người tiêu dùng chứng minh được khuyết tật sản phẩm là do lỗi bất cẩn của nhà sản xuất.

Tuy nhiên, nguyên tắc trách nhiệm do lỗi bất cẩn vẫn chưa thực sự bảo vệ quyền lợi người tiêu dùng một cách hữu hiệu. Trong hầu hết các trường hợp, người tiêu dùng rất khó chứng minh lỗi của nhà sản xuất bởi chứng cứ thường do bị đơn kiểm soát.

Vì vậy, học thuyết về "trách nhiệm nghiêm ngặt" (strict liability) đã ra đời vào khoảng giữa thập kỷ 1940. Theo đó, nhà sản xuất phải chịu trách nhiệm đối với khuyết tật của sản phẩm ngay cả khi họ không có lỗi. Điều này khuyến khích các nhà sản xuất phải thiết kế và chế tạo các sản phẩm an toàn hơn. Nếu lý giải học thuyết này từ giác độ kinh tế-luật (phân tích chi phí - lợi ích), việc quy trách nhiệm nghiêm ngặt cho nhà sản xuất sẽ hạn chế rủi ro ở mức thấp nhất bởi nhà sản xuất ở vị thế tốt hơn so với người tiêu dùng trong việc giảm thiểu thiệt hại xảy ra. Hơn nữa, trách nhiệm nghiêm ngặt còn góp phần phân tán tổn thất, rủi ro trong xã hội, để chi phí do thiệt hại xảy ra sẽ không phải do một mình nạn nhân phải gánh chịu, mà chuyển qua cho nhà sản xuất, từ đó nhà sản xuất có thể chuyển hóa chi phí này vào giá thành và phân tán tổn thất cho tất cả những người tiêu dùng khác. Nói cách khác, các học giả theo trường phái kinh tế-luật cho rằng nghĩa vụ gánh chịu tổn thất do việc sử dụng sản phẩm có khuyết tật gây ra cần phải được gánh chịu bởi các chủ thể nào ở vị thế tốt hơn trong việc kiểm soát nguy hiểm hoặc có thể phân chia tổn thất đó một cách công bằng, bình đẳng khi thiệt hại xảy ra: đó chính là nhà sản xuất, kể cả khi nhà sản xuất không có lỗi [2].

Cùng với sự ra đời của học thuyết trách nhiệm nghiêm ngặt, đến thập kỷ 1960, học thuyết về mối liên hệ hợp đồng - rào cản truyền thống đối với nguyên đơn là người tiêu dùng trong các vụ kiện chống lại nhà sản xuất, đã nhường chỗ cho học thuyết về "vi phạm nghĩa vụ bảo đảm ngầm định" (implied warranty). Theo đó, kể cả trong trường hợp giữa nhà sản xuất và người tiêu dùng không trực tiếp xác lập hợp đồng với nhau, nhưng khi nhà sản xuất đã đưa sản phẩm vào các kênh thương mại để tiêu thụ bởi công chúng, thì coi như nhà sản xuất đã ký kết một bảo đảm ngầm định với người tiêu dùng rằng sản phẩm đó đáp ứng yêu cầu về tính thương mại (merchantability) và phù hợp với công dụng dự kiến (fitness for intended purpose).

Như vậy, đến nay, có ba học thuyết cơ bản để áp dụng trách nhiệm sản phẩm là học thuyết về sự bất cẩn (negligence), học thuyết về vi phạm nghĩa vụ bảo đảm của nhà sản xuất (breach of warranty) và học thuyết về "trách nhiệm nghiêm ngặt" (strict liability). Sự phát triển của pháp luật về trách nhiệm sản phẩm cho thấy với nhu cầu bảo vệ người tiêu dùng ngày càng gia tăng trong xã hội công nghiệp hiện đại, pháp luật trách nhiệm sản phẩm đã từng bước được hoàn thiện, phạm vi áp dụng trách nhiệm được mở rộng hơn, cung cấp cho người tiêu dùng các công cụ pháp lý hữu hiệu hơn để đòi lại công bằng cho họ trong trường hợp bị thiệt hại do sản phẩm có khuyết tật gây ra.

Hiện nay, pháp luật các nước trên thế giới vẫn có những điểm khác biệt nhất định về phạm vi trách nhiệm sản phẩm, về căn cứ xác định trách nhiệm. Giới doanh nghiệp và các công ty bảo hiểm cũng vận động hành lang một cách 
quyết liệt để quy định thêm các giới hạn của trách nhiệm sản phẩm. Điều đó cho thấy bản chất của pháp luật trách nhiệm sản phẩm chính là phải thiết lập sự cân bằng giữa lợi ích của doanh nghiệp, yêu cầu phát triển kinh tế với lợi ích của công chúng, lợi ích của người tiêu dùng. Dù có những khác biệt hay tranh luận về trách nhiệm sản phẩm, các nước hiện nay thừa nhận rằng trách nhiệm sản phẩm là một công cụ pháp lý không thể thiếu để bảo vệ lợi ích người tiêu dùng, nhất là trong bối cảnh toàn cầu hóa và sự phát triển của cách mạng công nghiệp 4.0, khi nền sản xuất được tự động hóa một cách cao độ.

\section{Khái niệm và đặc điểm của trách nhiệm sản phẩm}

Trách nhiệm sản phẩm (product liability) là trách nhiệm của người sản xuất hoặc người bán hàng trong việc bồi thường các thiệt hại gây ra bởi khuyết tật của hàng hóa mà họ đã cung cấp cho người tiêu dùng trong quá trình kinh doanh. Như vậy, trách nhiệm sản phẩm có những đặc điểm sau:

Thứ nhất, trách nhiệm sản phẩm là một loại trách nhiệm bồi thường thiệt hại, đó là là trách nhiệm pháp lý của người sản xuất, người cung ứng sản phẩm hàng hoá đối với an toàn về sức khoẻ, tính mạng của người tiêu dùng. Về bản chất, trách nhiệm sản phẩm là một dạng trách nhiệm dân sự, theo đó khi có thiệt hại xảy ra, pháp luật quy định buộc các chủ thể nhất định (chủ thể trực tiếp gây thiệt hại hoặc có liên quan đến việc gây ra thiệt hại) phải bù đắp những thiệt hại đã gây ra cho người khác dựa trên căn cứ pháp luật về bồi thường thiệt hại ngoài hợp đồng hoặc do vi phạm nghĩa vụ theo hợp đồng. Như đã phân tích ở trên, theo pháp luật trách nhiệm sản phẩm hiện đại, việc xác định trách nhiệm sản phẩm không nhất thiết chỉ dựa vào quan hệ hợp đồng giữa người bị thiệt hại và nhà sản xuất, cung ứng sản phẩm. Mối liên hệ giữa người phải chịu trách nhiệm và người bị thiệt hại được xác định thông qua một sản phẩm, theo đó, người phải chịu trách nhiệm là người sản xuất hoặc cung ứng sản phẩm và người được bồi thường thiệt hại là người tiêu dùng sản phẩm đó, giữa họ có thể có quan hệ hợp đồng trực tiếp hoặc không có quan hệ hợp đồng

Thứ hai, chủ thể gánh chịu trách nhiệm sản phẩm là người sản xuất hoặc người bán hàng, tức là một chủ thể tham gia vào quy trình đưa một sản phẩm đến người tiêu dùng, có mối liên hệ trực tiếp đối với sản phẩm [4]. Chủ thể đó có thể là: (i) người sản xuất ra sản phẩm (bao gồm cả người sản xuất ra sản phẩm hoàn chỉnh hoặc là người sản xuất ra một phần, một bộ phận trong sản phẩm hoàn chỉnh đó); (ii) người thực hiện vai trò phân phối trung gian đối với sản phẩm (các nhà bán buôn, nhà phân phối) hoặc (iii) người cung cấp sản phẩm đến tận tay của người tiêu dùng (ví dụ: các cửa hàng bán lẻ).

Thứ ba, cơ sở để xác định trách nhiệm sản phẩm là việc sản phẩm có khuyết tật và khuyết tật đó gây ra thiệt hại cho người tiêu dùng. Khuyết tật của sản phẩm tồn tại dưới ba dạng: khuyết tật trong quá trình sản xuất, khuyết tật trong thiết kế sản phẩm, khuyết tật trong việc tiếp thị, quảng cáo sản phẩm (không cảnh báo nguy cơ mất an toàn cho người tiêu dùng).

\section{Pháp luật về trách nhiệm sản phẩm của Hoa Kỳ}

Hoa Kỳ là nước tiên phong trong việc hình thành pháp luật về trách nhiệm sản phẩm. Đến nay, pháp luật Hoa Kỳ thừa nhận cả ba học thuyết về trách nhiệm sản phẩm: sự bất cẩn, trách nhiệm nghiêm ngặt và vi phạm nghĩa vụ bảo đảm. Hai lĩnh vực pháp luật được áp dụng phổ biến để quy trách nhiệm sản phẩm là pháp luật về bồi thường thiệt hại (torts law) và pháp luật về hợp đồng (đặc biệt là Điều $2-313$ và 2314 Bộ luật thương mại thống nhất UCC quy định về các bảo đảm công khai và bảo đảm ngầm định của bên bán).

\subsection{Trách nhiệm sản phẩm dụa trên sự bất cẩn}

Trong trường hợp người tiêu dùng yêu cầu bồi thường đối với sản phẩm khuyết tật do sự bất cẩn, họ phải chứng minh được bốn yếu tố: (1) nhà sản xuất có nghĩa vụ cẩn trọng hợp lý (reasonable care) trong việc sản xuất sản phẩm 
an toàn, (2) nhà sản xuất đã vi phạm nghĩa vụ đó bằng việc không loại trừ các nguy cơ mất an toàn có thể dự liệu trước, (3) có thiệt hại xảy ra và (4) có mối quan hệ nhân quả giữa sự vi phạm nghĩa vụ của nhà sản xuất và thiệt hại xảy ra. Trong đó, yếu tố thứ hai (nhà sản xuất đã vi phạm nghĩa vụ cẩn trọng - tức là có lỗi bất cẩn) là yếu tố khó chứng minh nhất.

Các trường hợp bất cẩn có thể là: bất cẩn trong khâu sản xuất (lắp ráp bất cẩn, sử dụng nguyên vật liệu, bao bì không phù hợp), bất cẩn trong việc kiểm tra sản phẩm, bất cẩn trong việc không cảnh báo đầy đủ về nguy hiểm hoặc khuyết tật, bất cẩn trong việc thiết kế.

\subsection{Trách nhiệm nghiêm ngặt}

Trách nhiệm nghiêm ngặt là cơ sở thuận lợi nhất cho yêu cầu đòi bồi thường thiệt hại do khuyết tật của sản phẩm. Trách nhiệm nghiêm ngặt được hiểu là người sản xuất phải chịu trách nhiệm nếu như sản phẩm có khuyết tật và việc sử dụng sản phẩm có khuyết tật này trong điều kiện bình thường gây ra những thiệt hại cho người sử dụng, người khởi kiện không cần chứng minh có hay không có sự bất cẩn của nhà sản xuất, có hay không có nghĩa vụ đảm bảo.

Năm 1965, Bộ diễn giải Luật bồi thường thiệt hại (phiên bản lần thứ hai) (Restatement (Second) of Torts) do Viện luật Hoa Kỳ soạn thảo - được coi như một nguồn luật có tính chất tham khảo về bồi thường thiệt hại được các tòa án áp dụng phổ biến - đã chính thức ghi nhận nguyên tắc "trách nhiệm nghiêm ngặt" (Điều 402A). Sau đó, từng bước, các tòa án mở rộng phạm vi áp dụng không chỉ đối với sản phẩm có khuyết tật trong khâu sản xuất, mà cả với sản pthẩm có khuyết tật do thiết kế và khiếm khuyết trong quảng cáo, tiếp thị (không cảnh báo cho người tiêu dùng về nguy cơ của sản phẩm). Năm 1998, Bộ diễn giải Luật bồi thường thiệt hại (phiên bản lần thứ ba) (Restatement (Third) of Torts) tiếp tục hoàn thiện các quy định về trách nhiệm sản phẩm theo học thuyết trách nhiệm nghiêm ngặt và Bộ diễn giải này được hầu hết tòa án của các bang áp dụng.

Nguyên tắc trách nhiệm nghiêm ngặt ban đầu được ghi nhận tại Điề̀u 420A Bộ diễn giải
Luật bồi thường thiệt hại (phiên bản lần thứ 2) như sau:

1. Người nào bán sản phẩm trong tình trạng có khuyết tật gây nguy hiểm một cách phi lý cho người sử dụng hoặc người tiêu dùng hoặc cho tài sản của họ thì phải chịu trách nhiệm đối với thiệt hại về thân thể gây ra bởi khuyết tật đó cho người sử dụng cuối hoặc người tiêu dùng, hoặc cho tài sản của người đó, nếu:

i) người bán là thương nhân kinh doanh sản phẩm đó, và

ii) sản phẩm được kỳ vong và thưc tế được đưa đến người sủ dụng và người tiêu dùng mà không có thay đổi đáng kể về tình trạng sản phẩm so với khi nó được bán.

2. Quy định ở khoản 1 vẫn áp dụng kể cả khi:

i) ngườ bán đã thưc hiện mọi sự cẩn trọng có thể trong việc sản xuất và bán sản phẩm, và

ii) người sủ dụng hay người tiêu dùng không mua sản phẩm tù ngườ bán hoặc không có bất kỳ quan hệ hợp đồng nào với người bán.

Nhu vậy, để áp dụng trách nhiệm nghiêm ngặt theo quy định trên phải thỏa mãn bốn yếu tố:

Một là, ngườ bán là thuoong nhân kinh doanh sản phẩm đó, có thể là nhà sản xuất, người bán buôn hoăc người bán lẻ.

Hai là, sản phẩm phải được bán ra trong tình trạng có khuyết tật và nguy hiểm một cách phi lý cho người dùng do tình trạng khuyết tật đó. Tiêu chí để xác định tình trạng khuyết tật của sản phẩm là sản phẩm có đáp ứng vọng hợp lý của một người tiêu dùng bình thường hay không (consumer reasonable expectation). Sản phẩm nguy hiểm một cách phi lý là sản phẩm nguy hiểm tới mức một người tiêu dùng bình thường không thể dự liệu được nguy cơ đó một cách hợp lý.

Ba là, tình trạng nguy hiểm phi lý đó gây ra thiệt hại cho người tiêu dùng

Bốn là, sản phẩm không được biến đổi một cách đáng kể sau khi bán. Trong trường hợp sản phẩm đã được biến đổi bởi nguyên đơn hoặc người khác sau khi bán và sự biến đổi đó góp phần gây ra thiệt hại thì bị đơn không phải chịu trách nhiệm.

Tuy nhiên, trong quá trình áp dụng Điều 420A nói trên đã nảy sinh nhiều vướng mắc, trong đó có vướng mắc trong việc xác định như 
thế nào là "tình trạng nguy hiểm phi lý" và vướng mắc trong việc áp dụng quy định này đối với khuyết tật do thiết kế. Bộ diễn giải Luật bồi thường thiệt hại (phiên bản lần thứ ba) đã khắc phục những vướng mắc này. Điều 2 Bộ diễn giải lần thứ ba này đưa ra định nghĩa rõ ràng mang tính phân biệt về ba loại khuyết tật sản phẩm. Theo đó:

Một sản phẩm có khuyết tật khi, tại thời điểm bán hoạc phân phối, nó chứa đựng khuyết tật trong sản xuất, có khuyết tật trong thiết kế, hoạc có khuyết tật do sự chỉ dần hoạc cảnh báo không đầy đủ. Một sản phẩm:

i) Chứa dưng khuyết tật trong sản xuất khi sản phẩm đó khác so với thiết kế mặc dù đã thực hiên moi sư cẩn trọng có thể trong viẹc sản xuất và tiếp thị sản phẩm đó;

ii) Có khuyết tật trong thiết kế khi rủi ro gây thiệt hại có thể lường trước của sản phẩm đã có thể giảm thiểu hoạc tránh được bằng việc sư dụng một thiết kế thay thế hợp lý bởi người bán hoạc người phân phối khác, hoặc một chủ thể đứng trước trong chuỗi phân phối thuoong mại, và việc bỏ sót thiết kế thay thế này khiến cho sản phẩm không an toàn một cách hợp lý;

iii) Có khuyết tật do sự chì dẫn hoạc cảnh báo không đầy đủ khi khi rủi ro gây thiệt hại có thể luờng trước của sản phẩm đã có thể giảm thiểu hoạc tránh được bằng việc cung cấp chi dẫn hoạc cảnh báo hợp lý bởi người bán hoạc người phân phối khác, hoặc một chủ thể đứng truớc trong chuối phân phối thương mại, và việc bỏ sót chi dẫn hoạc cảnh báo này khiến cho sản phẩm không an toàn một cách hợp lý;

Đối với khuyết tật trong sản xuất, pháp luật Hoa Kỳ sử dụng tiêu chí "sự kỳ vọng của người tiêu dùng" để xác định bởi khuyết tật về sản xuất làm thất vọng sự mong đợi hợp lý của người tiêu dùng [5;898]. Tiêu chí cụ thể để xác định khuyết tật sản xuất là liệu trong quá trình sản xuất, sản phẩm có bị sai khác so với thiết kế của nó hay không. Điều này sẽ chỉ xảy ra đối với một hoặc một số sản phẩm.

Đối với khuyết tật trong thiết kế, pháp luật Hoa Kỳ sử dụng phương pháp cân bằng giữa rủi ro và lợi ích để xác định, tức là tòa án sẽ phải đánh giá, phân tích nhiều yếu tố như: tính hữu ích của sản phẩm, các khía cạnh an toàn của sản phẩm, khả năng có mẫu thiết kế thay thế hợp lý, và liệu mẫu thiết kế thay thế hợp lý có làm phát sinh các mối nguy hiểm khác cho sản phẩm hay không [5; 900].

Đối với khuyết tật trong cảnh báo, nguyên đơn phải chứng minh rằng nhà sản xuất không cung cấp chỉ dẫn hoặc cảnh báo đầy đủ về sản phẩm. Để xác định như thế nào là một cảnh báo có khiếm khuyết, các tòa án xem xét nội dung và sự toàn diện, tính chất mạnh mẽ trong cách thể hiện, và đặc điểm của nhóm người sử dụng sản phẩm kỳ vọng. Nhà sản xuất cũng phải cảnh báo về các rủi ro không mang tính hiển nhiên và không được biết đến thông thường để người tiêu dùng có thể đưa ra một quyết định với đầy đủ thông tin về việc có hay không tiếp tục sử dụng sản phẩm đó. Tuy nhiên, nhà sản xuất thường không phải chịu trách nhiệm do không cảnh báo người tiêu dùng về rủi ro mang tính hiển nhiên và được biết đển thông thường [5; 906-907].

Về các trường hợp miễn trách nhiệm, Bộ diễn giải Luật bồi thường thiệt hại lần thứ 3 quy định nhà sản xuất không phải chịu trách nhiệm nếu nguyên đơn không thể chứng minh được rằng khuyết tật tồn tại vào thời điểm sản phẩm rời khỏi tay nhà sản xuất. Ngoài ra còn có các trường hợp miễn trách nhiệm hoặc giảm mức bồi thường như sử dụng sản phẩm không đúng, biến đổi hoặc thay đổi sản phẩm. "Tính phù hợp với tình trạng kỹ thuật" (state of the art) cũng là một căn cứ thường được các nhà sản xuất viện dẫn để được miễn trách nhiệm đối với khuyết tật sản phẩm do thiết kế. Tình trạng kỹ thuật được hiểu là thiết kế sản phẩm phù hợp với thông lệ của ngành, phản ánh công nghệ an toàn nhất và tiên tiến nhất đã được phát triển và đang được sử dụng trong thương mại, hoặc nó phản ánh công nghệ tiến bộ nhất với tri thức khoa học hiện có [5; 905].

\subsection{Vi phạm nghĩa vu bảo đảm (warranty)}

Nghĩa vụ bảo đảm sản phẩm cũng là một trong các cơ sở quan trọng để áp đặt trách nhiệm sản phẩm. Trách nhiệm của người sản xuất và cung ứng là phải bảo đảm chất lượng sản phẩm của mình. Nghĩa vụ bảo đảm được 
quy định trong Bộ luật thương mại thống nhất (UCC). Có ba nghĩa vụ bảo đảm là: bảo đảm công khai (express warranty) được quy định tại Điều 2-313 UCC; bảo đảm ngầm định về tính thương mại của sản phẩm (implied warranty of merchantability) và bảo đảm ngầm định về tính phù hợp với công dụng của sản phẩm (implied warranty of fitness for intended purpose) được quy định tại Điều 2-314 UCC. Bảo đảm công khai được hình thành bởi sự khẳng định hay cam kết của người bán liên quan đến hàng bán về việc hàng bán sẽ phù hợp với khẳng định hay cam kết đó. Bảo đảm ngầm định về tính thương mại luôn xuất hiện trong hợp đồng mua bán hàng hóa nếu như người bán là thương nhân kinh doanh mặt hàng đó và trong hợp đồng không đưa ra sự thay đổi hoặc loại trừ nào đối với tính thương mại của sản phẩm; khi đó, hàng hóa được coi là mang tính thương mại theo những tiêu chuẩn chung đối với sản phẩm cùng loại. Bảo đảm về công dụng, về tính thích hợp với một công dụng cụ thể chỉ xuất hiện khi người bán hay người cung ứng có cơ sở tin rằng người mua mua sản phẩm để nhằm một mục đích cụ thể nhất định và người mua dựa vào kỹ năng, kinh nghiệm và đánh giá của người bán hay người cung ứng khi chọn sản phẩm đó.

\section{Pháp luật về trách nhiệm sản phẩm của Liên minh châu Âu}

Liên minh châu Âu (EU) đã xây dựng một khung pháp lý khá toàn diện về trách nhiệm sản phẩm nhằm nỗ lực hài hòa hóa pháp luật về trách nhiệm sản phẩm của các quốc gia thành viên. Các nguyên lý cơ bản về trách nhiệm sản phẩm được thể hiện khá rõ trong Chỉ thị 85/374/EEC của Liên minh Châu Âu ngày 25/ 7/1985 về trách nhiệm sản phẩm, trong đó nổi bật là nguyên lý trách nhiệm nghiêm ngặt. Chỉ thị này đã được sửa đổi bởi Chỉ thị số 1999/34/EC do Nghị viện và Hội đồng Liên minh Châu Âu ban hành ngày 25 tháng 5 năm 1999. Theo các Chỉ thị nói trên, nhà sản xuất phải chịu trách nhiệm đối với thiệt hại do sản phẩm bị khiếm khuyết gây ra (Điều 1). Theo Điều 3 Chỉ thị, "nhà sản xuất" được định nghĩa rộng, bao gồm nhà sản xuất sản phẩm hoàn chỉnh, nhà sản xuất nguyên vật liệu thô, hoặc nhà sản xuất một bộ phận của sản phẩm, và bất kỳ người nào, bằng việc gắn tên, nhãn hiệu hoặc dấu hiệu phân biệt khác lên sản phẩm, thể hiện rằng mình là người sản xuất. Ngoài $\mathrm{ra}$, nhà sản xuất còn bao gồm bất kỳ người nào nhập khẩu vào $\mathrm{EU}$ một sản phẩm để bán, cho thuê hoặc bất kỳ hình thức phân phối nào trong hoạt động kinh doanh của mình. Trong trường hợp không thể xác định được nhà sản xuất sản phẩm thì nhà cung cấp được coi là nhà sản xuất, trừ trường hợp nhà cung cấp thông báo danh tính của nhà sản xuất cho người tiêu dùng.

Về nghĩa vụ chứng minh, Điều 4 Chỉ thị quy định người tiêu dùng bị thiệt hại phải chứng minh ba yếu tố: (1) có thiệt hại xảy ra cho người tiêu dùng, (2) sản phẩm có khuyết tật, và (3) có mối quan hệ nhân quả giữa khuyết tật của sản phẩm và thiệt hại xảy ra.

Theo Điều 6 của Chỉ thị, sản phẩm có khuyết tật khi nó không đảm bảo sự an toàn cho một người có quyền kỳ vọng sự an toàn đó, có xem xét tất cả các yếu tố có liên quan, bao gồm: (a) việc trình bày sản phẩm; (b) công dụng của sản phẩm mà có thể được kỳ vọng một cách hợp lý, (c) thời gian mà sản phẩm được đưa vào lưu thông. Sản phẩm không thể bị coi là có khuyết tật chỉ vì lý do là sau đó có một sản phẩm tốt hơn được đưa vào lưu thông. Như vậy, Chỉ thị của Liên minh châu Âu dựa vào tiêu chí "sự kỳ vọng hợp lý của người tiêu dùng" (consumer expectation test) để đánh giá khuyết tật sản phẩm hơn là dựa vào tiêu chí về cân bằng giữa rủi ro và lợi ích (risk/utility balancing test). Tiêu chí rủi ro-lợi ích xác định liệu một thiết kế thay thế hợp lý sẽ có thể giảm được thiệt hại gây ra bởi sản phẩm khuyết tật hay không và liệu thiết kế đó sẽ có thể làm phát sinh rủi ro ở các bộ phận khác của sản phẩm hay không. Trong khi đó, tiêu chí "sự kỳ vọng của người tiêu dùng" xác định liệu sản phẩm có nguy hiểm một cách phi lý đối với người tiêu dùng và liệu sản phẩm không thể đáp ứng kỳ vọng hợp lý của người tiêu dùng hay không [5; 900]. Khác với pháp luật của Hoa Kỳ, Chỉ thị không đặt ra các định nghĩa cụ thể về khuyết tật 
trong sản xuất, khuyết tật trong thiết kế và khuyết tật trong cảnh báo.

Về các trường hợp miễn trách nhiệm, Điều 7 Chỉ thị quy định: nhà sản xuất sẽ không phải chịu trách nhiệm nếu chứng minh được:

i) Nhà sản xuất không đưa sản phẩm vào lưu thông; hoặc

ii) Có nhiều khả năng là khuyết tật gây ra thiệt hại đã không tồn tại vào thời điểm sản phẩm được đưa vào lưu thông bởi nhà sản xuất hoặc khuyết tật phát sinh sau thời điểm đó; hoặc

iii) Sản phẩm không được nhà sản xuất sản xuất ra để bán hoặc để phân phối dưới bất kỳ hình thức nào nhằm mục đích kinh tế và cũng không được sản xuất hoặc phân phối trong hoạt động kinh doanh của người đó; hoặc

iv) Khuyết tật xảy ra là do sản phẩm phải tuân thủ các quy định bắt buộc do cơ quan công quyền ban hành; hoặc

v) Tình trạng hiểu biết về khoa học và kỹ thuật tại thời điểm nhà sản xuất đưa sản phẩm vào lưu thông không thể phát hiện được sự tồn tại của khuyết tật; hoặc

vi) Trong trường hợp nhà sản xuất một bộ phận của sản phẩm, khuyết tật là do thiết kế tổng thể của sản phẩm mà bộ phận đó phải phù hợp hoặc là do chỉ dẫn của nhà sản xuất sản phẩm hoàn chỉnh đưa ra.

\section{Các quy định pháp luật Việt Nam về trách nhiệm sản phẩm}

\subsection{Giai đoạn truớc năm 2010}

Trước năm 2010, chế định trách nhiệm sản phẩm chưa hình thành chính thức ở Việt Nam. Văn bản pháp luật có hiệu lực pháp lý cao nhất ở Việt Nam về bảo vệ người tiêu dùng là Pháp lệnh bảo vệ người tiêu dùng năm 1999, bên dưới là các văn bản hướng dẫn thi hành Pháp lệnh này, tuy nhiên Pháp lệnh chưa quy định khái niệm trách nhiệm sản phẩm, khái niệm sản phẩm khuyết tật, nguyên tắc áp dụng trách nhiệm sản phẩm, vấn đề thu hồi sản phẩm có khuyết tật... Do đó, trên thực tế, tình trạng sản phẩm kém chất lượng gây thiệt hại cho người tiêu dùng xảy ra phổ biến nhưng không có đủ cơ sở pháp lý để xử lý, buộc các doanh nghiệp phải chịu trách nhiệm bồi thường. Trong khi đó, quyền lợi người tiêu dùng ngày càng bị xâm phạm tràn lan ở mọi lĩnh vực, mọi phương diện của nền kinh tế và đời sống xã hội, đặc biệt là các sản phẩm thiết yếu như thực phẩm, quần áo, mỹ phẩm,...

Điều 630 Bộ luật dân sự năm 2005 (Bồi thường thiệt hại do vi phạm quyền lợi của người tiêu dùng) quy định: Cá nhân, pháp nhân, chủ thể khác sản xuất, kinh doanh không bảo đảm chất lượng hàng hóa mà gây thiệt hại cho người tiêu dùng thì phải bồi thường. Năm 2007, Luật Chất lượng sản phẩm, hàng hóa được ban hành, trong đó quy định các nghĩa vụ của tổ chức, cá nhân sản xuất, kinh doanh như tuân thủ các điều kiện bảo đảm chất lượng đối với sản phẩm trước khi đưa ra thị trường và chịu trách nhiệm về chất lượng sản phẩm do mình sản xuất; cảnh báo về khả năng gây mất an toàn của sản phẩm và cách phòng ngừa cho người bán hàng và người tiêu dùng; sửa chữa, hoàn lại hoặc đổi hàng mới, nhận lại hàng có khuyết tật bị người bán hàng, người tiêu dùng trả lại; thu hồi, xử lý sản phẩm, hàng hóa không bảo đảm chất lượng; bồi thường thiệt hại (Điều 10Nghĩa vụ của người sản xuất, Điều 12- Nghĩa vụ của người nhập khẩu, Điều 16 - Nghĩa vụ của người bán hàng). Đáng chú ý là Luật này dành riêng Mục 2, Chương $\mathrm{V}$ quy định trách nhiệm bồi thường thiệt hại về chất lượng sản phẩm, hàng hóa. Theo đó, nguyên tắc chung là thiệt hại do vi phạm quy định về chất lượng sản phẩm, hàng hóa phải được bồi thường toàn bộ và kịp thời (Điều 59). Các thiệt hại phải bồi thường do hàng hóa không bảo đảm chất lượng bao gồm: thiệt hại về giá trị hàng hóa, tài sản bị hư hỏng hoặc bị hủy hoại; thiệt hại về tính mạng, sức khỏe con người; thiệt hại về lợi ích gắn liền với việc sử dụng, khai thác hàng hóa, tài sản; chi phí hợp lý để ngăn chặn, hạn chế và khắc phục thiệt hại (Điều 60). Chủ thể chịu trách nhiệm bồi thường thiệt hại bao gồm: người sản xuất, người nhập khẩu phải bồi thường thiệt hại cho người bán hàng hoặc người tiêu dùng khi hàng hóa gây thiệt hại do lỗi của người sản xuất, người nhập khẩu không bảo 
đảm chất lượng hàng hóa; người bán hàng phải bồi thường thiệt hại cho người mua, người tiêu dùng trong trường hợp thiệt hại phát sinh do lỗi của người bán hàng không bảo đảm chất lượng hàng hóa. (Điều 61). Điều 62 của Luật quy định các trường hợp không phải bồi thường thiệt hại cho người tiêu dùng như sau: người tiêu dùng sử dụng hàng hóa đã hết hạn sử dụng; đã hết thời hiệu khiếu nại, khởi kiện; đã thông báo hàng hóa có khuyết tật đến người tiêu dùng nhưng người tiêu dùng vẫn sử dụng hàng hóa đó; sản phẩm, hàng hóa có khuyết tật do tuân thủ quy định bắt buộc của cơ quan nhà nước có thẩm quyền; trình độ khoa học, công nghệ của thế giới chưa đủ để phát hiện khả năng gây mất an toàn của sản phẩm tính đến thời điểm hàng hóa gây thiệt hại; thiệt hại phát sinh do lỗi của người mua, người tiêu dùng.

Như vậy, Bộ luật dân sự năm 2005 và Luật Chất lượng sản phẩm, hàng hóa năm 2007 đã bước đầu quy định về trách nhiệm bồi thường thiệt hại của nhà sản xuất, người bán hàng đối với hàng hóa không bảo đảm chất lượng, tuy nhiên Luật Chất lượng sản phẩm, hàng hóa sử dụng không thống nhất các thuật ngữ, có lúc sử dụng thuật ngữ "hàng hóa không bảo đảm chất lượng", có lúc sử dụng thuật ngữ "hàng hóa có khuyết tật", có lúc lại sử dụng thuật ngữ "sản phẩm, hàng hóa có khả năng gây mất an toàn" (Điều 3 khoản 4) và không có định nghĩa về hàng hóa có khuyết tật hay hàng hóa không bảo đảm chất lượng. Luật Chất lượng sản phẩm, hàng hóa quy định trách nhiệm bồi thường thiệt hại phát sinh phải dựa trên cơ sở lỗi của người sản xuất, người bán hàng, nhưng quy định nhiều trường hợp loại trừ trách nhiệm này. Trong giai đoạn trước năm 2010 cũng không ghi nhận được trường hợp nào tòa án xét xử tranh chấp về bồi thường thiệt hại do nhà sản xuất, người bán hàng cung cấp hàng hóa không bảo đảm chất lượng cho người tiêu dùng.

\subsection{Giai đoạn tù̀ năm 2010 đến nay}

Năm 2010, Luật Bảo vệ quyền lợi người tiêu dùng được ban hành đã có những quy định cụ thể hơn về trách nhiệm sản phẩm. Luật đã đưa ra khái niệm hàng hóa có khuyết tật, đó là hàng hóa không bảo đảm an toàn cho người tiêu dùng, có khả năng gây thiệt hại cho tính mạng, sức khỏe, tài sản của người tiêu dùng, kể cả trường hợp hàng hóa đó được sản xuất theo đúng tiêu chuẩn hoặc quy chuẩn kỹ thuật hiện hành nhưng chưa phát hiện được khuyết tật tại thời điểm hàng hóa được cung cấp cho người tiêu dùng, bao gồm: (i) Hàng hóa sản xuất hàng loạt có khuyết tật phát sinh từ thiết kế kỹ thuật; (ii) Hàng hóa đơn lẻ có khuyết tật phát sinh từ quá trình sản xuất, chế biến, vận chuyển, lưu giữ; (iii) Hàng hóa tiềm ẩn nguy cơ gây mất an toàn trong quá trình sử dụng nhưng không có hướng dẫn, cảnh báo đầy đủ cho người tiêu dùng. Như vậy, Luật Bảo vệ quyền lợi người tiêu dùng chỉ quy định trách nhiệm sản phẩm đối với hàng hóa, không áp dụng đối với dịch vụ.

Về trách nhiệm thu hồi hàng hóa có khuyết tật, Điều 22 Luật Bảo vệ quyền lợi người tiêu dùng quy định: Khi phát hiện hàng hóa có khuyết tật, tổ chức, cá nhân sản xuất, nhập khẩu hàng hóa có trách nhiệm kịp thời tiến hành mọi biện pháp cần thiết để ngừng việc cung cấp hàng hóa có khuyết tật trên thị trường; thông báo công khai về hàng hóa có khuyết tật và việc thu hồi hàng hóa đó ít nhất 05 số liên tiếp trên báo ngày hoặc 05 ngày liên tiếp trên đài phát thanh, truyền hình tại địa phương mà hàng hóa đó được lưu thông (với các nội dung: mô tả hàng hóa phải thu hồi; lý do thu hồi hàng hóa và cảnh báo nguy cơ thiệt hại do khuyết tật của hàng hóa gây ra; thời gian, địa điểm, phương thức thu hồi hàng hóa; thời gian, phương thức khắc phục khuyết tật của hàng hóa; các biện pháp cần thiết để bảo vệ quyền lợi người tiêu dùng trong quá trình thu hồi hàng hóa); thực hiện việc thu hồi hàng hóa có khuyết tật đúng nội dung đã thông báo công khai và chịu các chi phí phát sinh trong quá trình thu hồi; báo cáo kết quả cho cơ quan quản lý nhà nước về bảo vệ quyền lợi người tiêu dùng cấp tỉnh nơi thực hiện thu hồi hàng hóa có khuyết tật sau khi hoàn thành việc thu hồi và nếu trường hợp việc thu hồi hàng hóa có khuyết tật được tiến hành trên địa bàn từ hai tỉnh trở lên thì báo cáo kết quả cho cơ quan quản lý nhà nước về bảo vệ quyền lợi người tiêu dùng ở trung ương. 
Về trách nhiệm bồi thường thiệt hại do hàng hóa có khuyết tật gây ra, Điều 23 của Luật quy định tổ chức, cá nhân kinh doanh hàng hóa có trách nhiệm bồi thường thiệt hại trong trường hợp hàng hóa có khuyết tật do mình cung cấp gây thiệt hại đến tính mạng, sức khỏe, tài sản của người tiêu dùng, kể cả khi tổ chức, cá nhân đó không biết hoặc không có lỗi trong việc phát sinh khuyết tật, trừ trường hợp miễn trách nhiệm được quy định tại Điều 24 của Luật. Tổ chức, cá nhân kinh doanh hàng hóa được hiểu bao gồm: Tổ chức, cá nhân sản xuất hàng hóa; Tổ chức, cá nhân nhập khẩu hàng hóa; Tổ chức, cá nhân gắn tên thương mại lên hàng hóa hoặc sử dụng nhãn hiệu, chỉ dẫn thương mại cho phép nhận biết đó là tổ chức, cá nhân sản xuất, nhập khẩu hàng hóa; Tổ chức, cá nhân trực tiếp cung cấp hàng hóa có khuyết tật cho người tiêu dùng. Việc bồi thường thiệt hại được thực hiện theo quy định của pháp luật về dân sự.

Các tổ chức, cá nhân kinh doanh hàng hóa nói trên được miễn trách nhiệm bồi thường thiệt hại khi chứng minh được khuyết tật của hàng hóa không thể phát hiện được với trình độ khoa học, kỹ thuật tại thời điểm tổ chức, cá nhân kinh doanh hàng hóa cung cấp cho người tiêu dùng. Như vậy, Luật Bảo vệ quyền lợi người tiêu dùng chỉ ghi nhận duy nhất một trường hợp được miễn trách nhiệm bồi thường liên quan đến hàng hóa có khuyết tật và trách nhiệm chứng minh này do tổ chức, cá nhân kinh doanh thực hiện.

Có thể thấy, các quy định về trách nhiệm sản phẩm trong Luật Bảo vệ quyền lợi người tiêu dùng đã có một số điểm tiến bộ, trong chừng mực nhất định có sự phù hợp với pháp luật trách nhiệm sản phẩm của các nước phát triển. Ví dụ, Luật đã ghi nhận đầy đủ ba dạng hàng hóa khuyết tật gồm khuyết tật trong thiết kế, khuyết tật trong sản xuất, khuyết tật trong cảnh báo và cụ thể hóa phạm vi các chủ thể có trách nhiệm bồi thường. Đặc biệt, Luật thừa nhận nguyên tắc trách nhiệm nghiêm ngặt (buộc tổ chức, cá nhân kinh doanh hàng hóa có trách nhiệm bồi thường thiệt hại kể cả khi họ không biết hoặc không có lỗi trong việc phát sinh khuyết tật). So với nhiều nước trong khu vực và thế giới, việc thừa nhận nguyên tắc này được xem là một bước tiến tích cực trong nhận thức về bảo vệ người tiêu dùng ở Việt Nam thời gian qua.

Mặc dù Luật Bảo vệ quyền lợi người tiêu dùng được ban hành, nhưng các quy định về bồi thường thiệt hại trong Luật Chất lượng sản phẩm, hàng hóa vẫn được giữ nguyên và còn hiệu lực, tạo nên sự chồng chéo, mâu thuẫn trong quy định về trách nhiệm bồi thường thiệt hại của tổ chức, cá nhân sản xuất kinh doanh đổi với hàng hóa có khuyết tật. Mâu thuẫn được thể hiện rõ qua các quy định về lỗi, về chủ thể chịu trách nhiệm, về thiệt hại được bồi thường, và các trường hợp miễn trách nhiệm.

Bên cạnh đó, Điều 608 Bộ luật dân sự năm 2015 (Bồi thường thiệt hại do vi phạm quyền lợi của người tiêu dùng), trên cơ sở kế thừa Điều 630 Bộ luật dân sự năm 2005 quy định: "Cá nhân, pháp nhân sản xuất, kinh doanh hàng hóa, dịch vụ không bảo đảm chất lượng hàng hóa, dịch vụ mà gây thiệt hại cho người tiêu dùng thì phải bồi thường". Như vậy, Bộ luật dân sự năm 2015 lại tạo nên sự không thống nhất với Luật Bảo vệ quyền lợi người tiêu dùng khi mở rộng trách nhiệm bồi thường thiệt hại đối với cả "dịch vụ" và sử dụng thuật ngữ "hàng hóa, dịch vụ không bảo đảm chất lượng" thay vì thuật ngữ "hàng hóa có khuyết tật".

Như vậy, hiện nay có 3 văn bản luật tồn tại đồng thời đều quy định về trách nhiệm bồi thường thiệt hại của nhà sản xuất, kinh doanh cho người tiêu dùng đối với sản phẩm có khuyết tật, với quy định không thống nhất với nhau, dẫn đến sự lúng túng, vướng mắc của tòa án trong việc áp dụng pháp luật để giải quyết tranh chấp, được minh họa qua các vụ việc thực tiễn được trình bày dưới đây.

\section{Thực tiễn xét xử một số vụ án yêu cầu bồi thường thiệt hại do vi phạm quyền lợi của người tiêu dùng ở Việt Nam trong những năm gần đây và đề xuất hoàn thiện pháp luật}

\subsection{Thực tiễn xét xủ}

Mặc dù Luật Bảo vệ quyền lợi người tiêu dùng đã có hiệu lực trên 8 năm, nhưng tình 
trạng xâm phạm quyền lợi người tiêu dùng ở Việt Nam vẫn diễn ra phổ biến và ngày càng phức tạp. Trong khi đó, có rất ít vụ việc được người tiêu dùng khởi kiện ra tòa án theo các quy định pháp luật dân sự về bồi thường thiệt hại do vi phạm quyền lợi người tiêu dùng, một phần do tâm lý tránh phiền phức, ngại đòi hỏi của đa số người tiêu dùng, phần vì các quy định pháp luật và thực tiễn áp dụng pháp luật của tòa án còn nhiều bất cập, chưa bảo vệ hiệu quả quyền lợi của người tiêu dùng. Trong khoảng 56 năm trở lại đây, chỉ có một vài vụ án dân sự trong đó người tiêu dùng khởi kiện nhà sản xuất yêu cầu bồi thường thiệt hại do sản phẩm không bảo đảm chất lượng.

Vu án thú nhất: Năm 2012, bà Q khởi kiện Công ty trách nhiệm hữu hạn liên doanh STADA - Việt Nam yêu cầu bồi thường thiệt hại vì bà đã uống thuốc tránh thai khẩn cấp do Công ty này sản xuất nhưng vẫn có thai và phải bỏ thai bởi lo ngại sẽ có biến chứng xấu. Tòa án cấp sơ thẩm đã bác yêu cầu khởi kiện của bà $\mathrm{Q}$ do nguyên đơn không chứng minh được các yếu tố cấu thành trách nhiệm bồi thường. $\mathrm{Bà} \mathrm{Q}$ kháng cáo, nhưng Tòa án cấp phúc thẩm giữ nguyên bản án sơ thẩm. Theo Tòa án cấp phúc thẩm, bà $\mathrm{Q}$ đã không chứng minh được bà có sử dụng viên thuốc tránh thai khẩn cấp hay không; bà $\mathrm{Q}$ cũng không chứng minh được mình đã sử dụng thuốc theo đúng nội dung hướng dẫn sử dụng thuốc. Ngoài ra, Tòa án lập luận rằng giả sử bà $\mathrm{Q}$. thực sự có sử dụng thuốc tránh thai theo đúng hướng dẫn nhưng vẫn có thai thì bị đơn cũng không có lỗi vì khuyến cáo trên sản phẩm đã ghi rõ "phương pháp tránh thai khẩn cấp không thể đạt hiệu quả trong mọi trường hợp" [6].

Bình luận: Trong vụ án này, Tòa án không đề cập đến quy định của Luật Bảo vệ quyền lợi người tiêu dùng hay Luật chất lượng sản phẩm, hàng hóa và không xác định đây có phải là trường hợp bồi thường thiệt hại do vi phạm quyền lợi người tiêu dùng hay không, mà chỉ áp dụng Bộ luật dân sự để giải quyết như một vụ án yêu cầu bồi thường thiệt hại ngoài hợp đồng thông thường, trong đó nguyên đơn phải chứng minh bốn yếu tố truyền thống cấu thành trách nhiệm là: có hành vi gây thiệt hại, có thiệt hại xảy ra, có lỗi của bị đơn, có mối quan hệ nhân quả. Trong khi đó, về bản chất, đây chính là một vụ án về trách nhiệm sản phẩm và tòa án cần lập luận chi tiết, chặt chẽ hơn về nghĩa vụ chứng minh của nguyên đơn cũng như các trường hợp miễn trách nhiệm.

Vu án thư hai: Bà Nguyễn Thị Bình Minh khởi kiện bị đơn là Công ty trách nhiệm hữu hạn Coca-Cola về việc bà mua một chai nước cam ép Splash với giá 10.000 đồng, bên trong chai nước có chứa vật thể lạ là hai ống thủy tinh vỡ và một mảnh giấy nhỏ màu trắng đục. Bà Minh yêu cầu Công ty bồi thường cho bà số tiền mua một chai nước cam ép; có văn bản giải thích rõ với người tiêu dùng vì sao lại có vật thể lạ trong sản phẩm và công khai xin lỗi bà Minh và người tiêu dùng nói chung trên 05 số báo liên tiếp. Tòa án đã áp dụng Điều 630 Bộ luật dân sự năm 2005 quy định tổ chức sản xuất kinh doanh "hàng hóa không đảm bảo chất lượng" thì phải bồi thường cho người tiêu dùng. Tuy nhiên, khi nhận định trong bản án thì Tòa án lại dùng thuật ngữ "hàng hóa có khuyết tật" là khái niệm được sử dụng trong Luật Bảo vệ quyền lợi người tiêu dùng năm 2010. Cụ thể Tòa án cho rằng "Vì hàng hóa (vật chứng mà nguyên đơn khởi kiện) không phải do CocaCola Việt Nam hoàn thiện (dập nắp) nên không có căn cứ xác định Coca Cola Việt Nam có lỗi đối với hàng hóa có khuyết tật mà nguyên đơn khởi kiện", "Do đó, không có căn cứ chấp nhận yêu cầu khởi kiện của nguyên đơn số tiền mua một chai nước cam ép Splash của Coca - Cola Việt Nam, yêu cầu giải thích với người tiêu dùng về nguyên nhân dẫn đến sự xuất hiện tạp chất, ống thủy tinh trong sản phẩm nước cam ép Splash và công khai xin lỗi về việc để sản phẩm khuyết tật lưu hành trên thị trường" [7].

Bình luận: Trong vụ án này, Tòa án đã đồng nhất giữa hai khái niệm "hàng hóa không đảm bảo chất lượng" và "hàng hóa có khuyết tật", nhận định giản đơn về lỗi của chủ thể chịu trách nhiệm (hàng hóa không phải do bị đơn dập nắp nên bị đơn không có lỗi). Điểm mấu chốt trong vụ việc này mà tòa án chưa phân tích là chưa có thiệt hại xảy ra cho người tiêu dùng - một yếu tố cần phải có trong vụ việc về trách nhiệm sản phẩm. Ở đây, người tiêu dùng mới chỉ có thiệt 
hại (không đáng kể) về kinh tế (mất tiền mua chai nước nhưng không sử dụng được). Tòa án chỉ áp dụng Điều 630 Bộ luật dân sự năm 2005 mà không đề cập quy định của Luật Bảo vệ quyền lợi người tiêu dùng hay Luật Chất lượng sản phẩm, hàng hóa.

Vu án thứ ba: Năm 2018, vợ chồng bà $\mathrm{T}$ khởi kiện Công ty $\mathrm{G}$ yêu cầu bồi thường thiệt hại 190 triệu đồng do năm 2016, vợ chồng bà T mua $2.000 \mathrm{~kg}$ phân bón NPK do Công ty G sản xuất về bón cho cây cà phê, tiêu và cây ăn quả trong vườn nhưng sau khi bón phân được 10 ngày thì cây bị vàng lá và chết hàng loạt. Sau đó ông bà có báo sự việc trên với đại lý phân bón; các bên lập 01 biên bản làm việc, cam kết thời hạn bồi thường là hết ngày 31-12-2016 nhưng Công ty không bồi thường như đã cam kết. Sau đó bà $\mathrm{T}$ làm đơn tố cáo gửi đến công an huyện $\mathrm{K}$ yêu cầu giải quyết. Cơ quan cảnh sát điều tra công an huyện $K$ thông báo cho bà T rằng không có đủ cơ sở để khởi tố vụ án hình sự đối với hành vi "buôn bán phân bón giả". Bản án sơ thẩm bác yêu cầu khởi kiện do nguyên đơn không cung cấp được chứng cứ chứng minh, cụ thể, mẫu phân bón mà ông bà cho là phân bón kém chất lượng được chính bà T lấy mẫu không đúng theo trình tự, thủ tục. Tòa án cấp phúc thẩm giữ nguyên bản án sơ thẩm và đồng tình với nhận định của cấp sơ thẩm [8].

Bình luận: Tòa án không viện dẫn quy định nào của Bộ luật dân sự, Luật Bảo vệ người tiêu dùng hay Luật Chất lượng sản phẩm, hàng hóa, không chỉ ra các yếu tố mà nguyên đơn cần chứng minh, chỉ hoàn toàn dựa vào quy định của Bộ luật tố tụng dân sự để khẳng định nguyên đơn chưa hoàn thành nghĩa vụ chứng minh, từ đó bác yêu cầu của nguyên đơn, do vậy lập luận trong bản án thiếu chặt chẽ, thuyết phục.

Vu án thứ tu: Ngày 02/10/2014 ông Kh mua 01 chiếc ti vi mới tại cửa hàng đại lý của công ty $\mathrm{S}$ để sử dụng cho gia đình, thời gian bảo hành 24 tháng kể từ ngày mua. Gia đình ông sử dụng tivi được hơn 9 tháng thì ti vi bị hỏng, nhân viên bảo hành của công ty đã đến sửa chữa tại nhà. Ông tiếp tục sử dụng ti vi bình thường được 2 tháng thì ti vi lại hỏng, nhân viên của trung tâm bảo hành có đến nhà ông xem xét và chụp ảnh chiếc ti vi có sự chứng kiến của ông. Sau đó trung tâm gọi điện thoại từ chối bảo hành và đưa ra lý do người tiêu dùng đã để nước vào ti vi và trời nồm ẩm gia đình không biết bảo quản. Ông đã nhiều lần gọi điện và trực tiếp đến tận trung tâm bảo hành của công ty để yêu cầu bảo hành nhưng không được giải quyết. Ông cho rằng ti vi bị hỏng là do sản phẩm này không đảm bảo chất lượng và nguyên nhân từ chối bảo hành không đúng. Ông Kh đã khiếu nại đến công ty $\mathrm{S}$ và đã nhận được thư giải quyết khiếu nại ghi "chấp thuận hỗ trợ đặc biệt là miễn phí toàn bộ sửa chữa", nhưng gia đình ông không chấp nhận, từ đó Công ty $\mathrm{S}$ không đển bảo hành và không có động thái nào khác. Ông Kh khởi kiện yêu cầu công ty $\mathrm{S}$ phải bồi thường cho gia đình tổng số tiền 802.300.000đ do bán sản phẩm không đảm bảo chất lượng và không bảo hành sản phẩm theo quy định, vi phạm quyền lợi gia đình ông. Tòa án cấp sơ thẩm xử bác toàn bộ yêu cầu khởi kiện của ông Kh. Ông Kh. kháng cáo cho rằng tòa án cấp sơ thẩm xác định sai nghĩa vụ chứng minh, vấn đề cần chứng minh và sai lầm trong đánh giá chứng cứ vì ông là người tiêu dùng không có nghĩa vụ chứng minh lỗi của nhà sản xuất. Tòa án cấp phúc thẩm nhận định rằng bị đơn đã cung cấp các chứng cứ chứng minh toàn bộ số hàng hóa là tivi sản xuất cùng thời điểm ti vi đã bán cho gia đình ông Kh không có sản phẩm nào bị lỗi như ti vi của ông $K h$. Nhân viên của công ty cũng đến kiểm tra lập biên bản hiện trạng và Tòa án cũng tiến hành xem xét thẩm định tại chỗ nhưng gia đình ông Kh không hợp tác, không cho xem xét thẩm định đối với chiếc tivi $\mathrm{S}$. Công ty $\mathrm{S}$ đã thiện chí sửa chữa miễn phí nhưng ông Kh không chấp nhận. Kết luận giám định của Bộ Công an cho thấy ti vi bị sọc đứng do mạch điều khiển bị hỏng, không xác định được nguyên nhân hỏng do bị tác động hay do tự nhiên. Chính sách bảo hành đã ghi rõ công ty $\mathrm{S}$ không bảo hành các trường hợp vì chất lỏng bị đổ vào sản phẩm. Do vậy sản phẩm ti vi $S$ của gia đình ông $K h$ mua của đại lý công ty $\mathrm{S}$ bị hư hỏng không phải lỗi của nhà sản xuất và công ty $\mathrm{S}$ không bảo hành sản phẩm là đúng sự thỏa thuận mua bán giữa khách hàng và phía 
công ty. Vì vậy, Tòa án cấp phúc thẩm kết luận rằng chiếc ti vi bị hỏng không xem được không phải là do lỗi kỹ thuật của nhà sản xuất và không phải là hàng hóa khuyết tật, và theo quy định tại khoản 1 Điều 42 của Luật bảo vệ quyền lợi người tiêu dùng thì người tiêu dùng là ông Kh cũng có nghĩa vụ cung cấp chứng cứ và chứng minh cho yêu cầu khởi kiện. Ông Kh đề nghị bồi thường nhưng xét thấy không có mối quan hệ nhân quả giữa lỗi và hậu quả nên không phát sinh nghĩa vụ bồi thường giữa các bên. Tòa án cấp phúc thẩm nhận định cấp sơ thẩm đã áp dụng đầy đủ quy định tại Điều 42 của Luật Bảo vệ người tiêu dùng và các điều luật về chứng cứ, chứng minh theo quy định của Bộ luật tố tụng dân sự để áp dụng trong việc giải quyết vụ án [9].

Bình luận: Có thể nói đây là bản án có lập luận chi tiết nhất trong số 4 vụ án nêu trên về trách nhiệm bồi thường do vi phạm quyền lợi người tiêu dùng, nhưng lập luận của Tòa án vẫn còn một số điểm chưa thuyết phục. Tòa án viện dẫn cả Điều 630 Bộ luật dân sự năm 2005 và Luật Bảo vệ quyền lợi người tiêu dùng, đồng thời mặc nhiên khẳng định chiếc ti vi hỏng không phải là "hàng hóa có khuyết tật" mà không giải thích. Các yếu tố cần chứng minh tuy đã được đề cập phần nào (như lỗi, mối quan hệ nhân quả) nhưng chưa được phân tích một cách thấu đáo.

\subsection{Nhận xét, đánh giá các quy định pháp luật} hiện hành tù̀ thưc tiến xét xủ và đề xuất hoàn thiện pháp luật

Qua 4 vụ án nêu trên, có thể rút ra những điểm chung và những bất cập sau đây trong thực tiễn xét xử tranh chấp về bảo vệ quyền lợi người tiêu dùng của Tòa án:

Thư nhất, trong cả 4 vụ án, Tòa án đều bác yêu cầu khởi kiện của người tiêu dùng vì họ không thực hiện được nghĩa vụ cung cấp chứng cứ và chứng minh, tuy nhiên, chỉ có duy nhất vụ án thứ 4 là Tòa án có lập luận tương đối chi tiết về nghĩa vụ chứng minh này theo quy định của Luật Bảo vệ quyền lợi người tiêu dùng. Trong các bản án còn lại, lập luận của Tòa án khá sơ sài, hời hợt, chưa chỉ rõ dựa những yếu tố nào cần chứng minh để cấu thành trách nhiệm bồi thường, nguyên đơn đã chứng minh được những yếu tố nào, những yếu tố nào chưa chứng minh được. Như vậy, trên thực tế, rất khó để người tiêu dùng có thể thắng kiện khi yêu cầu Tòa án bảo vệ quyền lợi cho mình.

Thư hai, các tòa án dường như đang có sự đồng nhất, lẫn lộn giữa khái niệm "hàng hóa không bảo đảm chất lượng" trong Bộ luật dân sự và "hàng hóa có khuyết tật" trong Luật Bảo vệ quyền lợi người tiêu dùng. Khái niệm "hàng hóa không bảo đảm chất lượng" có nội hàm rộng hơn khái niệm "hàng hóa có khuyết tật" bởi lẽ "hàng hóa có khuyết tật" phải là "hàng hóa không bảo đảm an toàn cho người tiêu dùng, có khả năng gây thiệt hại cho tính mạng, sức khỏe, tài sản của người tiêu dùng" (Khoản 3 Điều 3 Luật Bảo vệ quyền lợi người tiêu dùng). Khái niệm "sản phẩm có khuyết tật" trong pháp luật về trách nhiệm sản phẩm của Hoa Kỳ, EU và nhiều nước khác cũng đều chứa đựng yếu tố "nguy hiểm", "gây mất an toàn" cho người tiêu dùng, trong đó chủ yếu là an toàn về tính mạng, sức khỏe. Nếu chỉ đơn thuần là hàng hóa bị hỏng, không sử dụng được theo đúng công dụng hoặc mới gây thiệt hại về kinh tế cho người tiêu dùng thì cũng chưa được coi là "hàng hóa có khuyết tật". Như vậy, trong cả 4 vụ án trên đây, có lẽ chỉ vụ án thứ nhất và thứ hai liên quan đến hàng hóa khuyết tật, và chỉ vụ án thứ nhất có thể coi là có khả năng phát sinh trách nhiệm sản phẩm vì có thiệt hại thực tế về sức khỏe xảy ra cho người tiêu dùng.

Thứ $b a$, trong cả 4 vu án trên, Tòa án đều không áp dụng hoặc thậm chí không biết đến quy định về bồi thường thiệt hại trong Luật Chất lượng sản phẩm, hàng hóa, mà cho rằng tranh chấp về bồi thường thiệt hại liên quan đến quyền lợi của người tiêu dùng thì mặc nhiên áp dụng Bộ luật dân sự và Luật Bảo vệ quyền lợi người tiêu dùng, bất kể vụ việc có thuộc trường hợp "hàng hóa có khuyết tật" hay không. Như vậy, quy định của Luật Chất lượng sản phẩm, hàng hóa về bồi thường thiệt hại do hàng hóa không bảo đảm chất lượng rõ ràng không phát huy vai trò trên thực tế, nếu không muốn nói là được đặt không đúng vị trí. Đáng lẽ, Luật Chất lượng sản phẩm, hàng hoá phải là luật thiết lập 
các cơ chế hành chính cho việc kiểm soát chất lượng sản phẩm, hàng hoá khi đưa vào lưu thông thay vì quy định về trách nhiệm dân sự phát sinh trong trường hợp sản phẩm khuyết tật [10; 29].

Nguyên nhân chủ yếu dẫn đến sự lúng túng và lập luận thiếu chặt chẽ của các tòa án khi áp dụng pháp luật để giải quyết các vụ việc bồi thường thiệt hại do vi phạm quyền lợi người tiêu dùng là do các quy định hiện hành còn chồng chéo, mâu thuẫn, chưa đầy đủ, chưa hình thành một chế định pháp luật độc lập về trách nhiệm sản phẩm dựa trên các nguyên lý cơ bản như nguyên lý trách nhiệm do bất cẩn, nguyên lý trách nhiệm nghiêm ngặt và nguyên lý trách nhiệm do vi phạm nghĩa vụ bảo đảm ngầm định.

Chưa có sự thống nhất giữa quy định của Bộ luật dân sự và Luật Bảo vệ người tiêu dùng trong việc xác định các yếu tố cấu thành trách nhiệm bồi thường. Bộ luật dân sự dường như quy định rất rộng về trách nhiệm bồi thường của nhà sản xuất, kinh doanh khi sử dụng khái niệm "hàng hóa, dịch vụ không bảo đảm chất lượng" mà không làm rõ nội hàm của khái niệm này, liệu "hàng hóa không bảo đảm chất lượng" có đồng nghĩa với "hàng hóa có khuyết tật" trong Luật Bảo vệ người tiêu dùng hay không.

Các quy định liên quan đến trách nhiệm sản phẩm hiện nay chưa làm rõ cơ sở xác định trách nhiệm sản phẩm (các yếu tố cần chứng minh) theo ba nguyên tắc: bất cẩn, vi phạm nghĩa vụ bảo đảm và trách nhiệm nghiêm ngặt, chưa quy định rõ cách thức, tiêu chí xác định hàng hóa có khuyết tật theo ba dạng khác nhau, các trường hợp miễn trách nhiệm bồi thường đối với hậu quả do khuyết tật của hàng hóa gây ra còn chưa đầy đủ (Luật Bảo vệ người tiêu dùng mới quy định một trường hợp miễn trách nhiệm).

Có thể nói pháp luật trách nhiệm sản phẩm của Việt Nam vẫn còn khá sơ sài, thiếu vắng nhiều quy định, mặc khác còn có sự chồng chéo, không thống nhất giữa các văn bản luật. Do đó, pháp luật cần tiếp tục được bổ sung, hoàn thiện trên cơ sở tham khảo kinh nghiệm lập pháp và án lệ của các nước trên thế giới:

Một là, bỏ các quy định về bồi thường thiệt hại do hàng hóa không bảo đảm chất lượng trong Mục 2 Chương 5 Luật Chất lượng sản phẩm, hàng hóa.

Hai là, đảm bảo sự thống nhất, hài hòa trong quy định về trách nhiệm sản phẩm của Bộ luật dân sự năm 2015 và Luật Bảo vệ quyền lợi người tiêu dùng năm 2010 theo một trong hai phương án:

Phương án 1: bỏ Điều 608 Bộ luật dân sự năm 2015 và quy định chi tiết về trách nhiệm sản phẩm trong Luật Bảo vệ quyền lợi người tiêu dùng.

Phương án 2: giữ nguyên Điều 608 Bộ luật dân sự năm 2015 nhưng thống nhất sử dụng khái niệm "hàng hóa có khuyết tật" (là khái niệm đã được thừa nhận chung trong pháp luật về trách nhiệm sản phẩm trên thế giới) và đưa các quy định về trách nhiệm sản phẩm trong Luật Bảo vệ người tiêu dùng vào Bộ luật dân sự với tư cách là một trường hợp bồi thường thiệt hại cụ thể để tòa án dễ dàng trong việc áp dụng.

Ba là, dù được xây dựng theo phương án nào nêu trên thì các quy định pháp luật Việt Nam cũng cần làm rõ định nghĩa về các dạng hàng hóa có khuyết tật, các yếu tố mà nguyên đơn (người tiêu dùng) cần chứng minh, những loại thiệt hại nào được chấp nhận bồi thường, quy định bổ sung các trường hợp miễn trách nhiệm, nhằm bảo đảm cân bằng lợi ích giữa người tiêu dùng và các chủ thể sản xuất, kinh doanh.

\section{Lời cảm ơn}

Bài viết được thực hiện trong khuôn khổ Đề tài cấp Đại học Quốc gia Hà Nội, mã số QG.18.28 "Nghiên cứu cơ sở khoa học và thực tiễn, đề xuất giải pháp hoàn thiện pháp luật Việt Nam về sở hữu trí tuệ nhằm thực thi cam kết trong các hiệp định thương mại tự do (FTAs)" do PGS.TS Nguyễn Thị Quế Anh chủ nhiệm.

\section{Tài liệu tham khảo}

[1] Victoria Sherrow, Product Liability, Chelsea House Publishers, 2010. 
[2] Understanding Product Liability Law, http://www.csun.edu/ bz51361/gateway/product. pdf (truy cập ngày 19/8/2019)

[3] Lê Hồng Hạnh, Trương Hồng Quang, Các nguyên lý cơ bản của chế định trách nhiệm sản phẩm tại Hoa Kỳ và một số quốc gia trên thế giới, Tạp chí Nhà nước và Pháp luật số $2 / 2010$, tr. 35-42.

[4] Trần Thị Quang Hồng, Trương Hồng Quang, Một số vấn đề chung về chế định trách nhiệm sản phẩm và vai trò của chế định này dưới góc độ bảo vệ người tiêu dùng, Tạp chí Nhà nước và Pháp luật số 12/2010, tr. 25-34.

[5] Lauren Sterrett, Product Liability: Advancements in European Union Product Liability Law and a Comparison Betweeen the EU and U.S. Regime, Michigan State International Law Review, Vol. 23 (2015) 885.

[6] Kiện vì uống thuốc tránh thai mà vẫn có bầu, https://dantri.com.vn/phap-luat/kien-vi-uong- thuoc-tranh-thai-ma-van-co-bau-1362619850.htm (truy cập ngày 19/8/2019).

[7] Nguyễn Thị Mai, Xác định hàng hóa không đảm bảo chất lượng và hàng hóa có khuyết tật, https://tapchitoaan.vn/bai-viet/phap-luat/xacdinh-hang-hoa-khong-dam-bao-chat-luong-vahang-hoa-co-khuyet-tat (truy cập ngày 19/8/2019).

[8] Tòa án nhân dân tỉnh Đăk Nông, Bản án số 14/2019/DS-PT ngày 05/4/2019 về bồi thường thiệt hại ngoài hợp đồng, đăng trên trang web: congbobanan.toaan.gov.vn.

[9] Tòa án nhân dân tỉnh Hải Dương, Bản án số 19/2019/DS-PT ngày 13/5/2019 về tranh chấp bồi thường thiệt hại do vi phạm quyền lợi của người tiêu dùng, đăng trên trang web: congbobanan.toaan.gov.vn.

[10] Trương Hồng Quang, Hoàn thiện pháp luật về trách nhiệm sản phẩm nhằm nâng cao hiệu quả bảo vệ người tiêu dùng ở Việt Nam, Tạp chí Luật học số 12/2012. 